\title{
Relationship between External Debt Management Policies and Economic Growth in Nigeria (1970-2006)
}

\author{
Chris O. Udoka (Corresponding author) \\ Department of Banking \& Finance, Faculty of Management Sciences \\ University of Calabar, Calabar, Nigeria \\ Tel: +23-480-307-5898_E-mail: udokaco@yahoo.com \\ Roland A. Anyingang \\ Department of Banking \& Finance, Faculty of Management Sciences \\ University of Calabar, Calabar, Nigeria \\ Tel: +23-480-667-60027_E-mail: anyingangrol@yahoo.com
}

Received: September 30, $2010 \quad$ Accepted: October 7, 2010 doi:10.5430/ijfr.v1n1p2

\begin{abstract}
This study sought to appraise the relationship between external debt management policies on the economic growth of Nigeria from 1970-2006. One null hypothesis was formulated to determine the effect of external debt on Gross domestic investment, exchange rate, fiscal deficit, and terms of trade. Ex-post facto research design was adopted for the study. Ordinary least square multiple regression technique was used to analyzed data gathered for the study. The result of the findings revealed that, GDP, exchange rate, fiscal deficit, London Interbank offered rate, and terms of trade are the major determinants of external debt in Nigeria. The severity of the debt within the period is reflected in the country's inability to meet the debt service obligations particularly scheduled debt services in relation to its foreign currency earnings, it explains why the country had rescheduled its debt from time to time (first in 1986, 1989, 1991, and last in October 2000). Recommendations are made that the federal government should lay down well considered guideline for external loans. Defining the purpose, duration, moratorium requirements and commitments, negotiation fees etc including the conditions under which the government can approve and guarantee external loans. Also In view of the debt relief, government should ensure that spending impact on poverty reduction halts HIV/AIDS and malaria and addresses child and material mortality. Thus, the government should priorities its spending on health, education, water, infrastructure, power and agriculture.
\end{abstract}

Keywords: External debt, External debt management policies

\section{Introduction}

Debt is created by the act of borrowing. It is defined according to Oyejide (1985) as the resource or money use in an organization which is not contributed by its owner and does not in any other way belong to them. It is a liability represented by a financial instrument or other formal equivalent. In modern law, debt has no precise fixed meaning and may be regarded essentially as that which one person legally owes to another or an obligation that is enforceable by legal action to make payment of money.

When government borrows, the debt is a public debt. Public debts are either internal or external, incurred by the government through borrowing in the domestic and international markets so as to finance domestic investment. Debts are classified into two i.e. productive debt and dead weight debt. When a loan is obtained to enable the state or nation to purchase some sort of assets, the debt is said to be productive e.g. money borrowed for acquiring factories, electricity, refineries etc. However, debt undertaken to finance wars and expenses on current expenditures are dead weight debts. When a country obtains a loan from abroad, it means that the country can import from abroad goods and services to the value of the loan without at the same time having to export anything for exchange. When capital and interest have to be repaid, the same country will have to get the burden of exporting goods and service without receiving any imports in exchange. Internal loans do not have the type of burden exchange of goods and services. These two types of debt, however, require that the borrowers' future savings must cover the interest and principal payment (debt servicing).

The early eighties was a disastrous period for Nigeria. Two events characterized external borrowing during this period. 
First there was an emergence of import oriented consumption pattern which made the federal and state governments to go into external borrowing. Second, funds realized from these loans were invested on unproductive ventures. Towards the end of 1970 the level of external debt of Nigeria increased rapidly and the services of the debt in terms of payment of interest and principal posed severe pressure on the balance of payments (BOP) of the country.

Nigeria oil boom could rightly, be traced to the mid seventies when there was crisis in the middle east which led to an increase demand and sale of Nigeria oil. This resulted in considerable foreign exchange earnings by the government. However, towards the close of the decade, the international oil market started experiencing a glut and the prices of oil fell drastically low. Some concerned Nigeria planners reasoned rationally that the economy was in total brink of collapse. To avoid economic problems like inflation, political and social crisis inherent in the period (1980-1985) the government of Shagari opened the gate way to external borrowing

Actually, the borrowing was done with the hope that there would be a turn around in the international oil market perhaps in no distance future. It was equally, hoped that the borrowed external fund would be a turn around in the purchasing domestic goods. However; the expected turn around did not materialize. Rather it came to a point that the amount borrowed (that is external debt) was greater than the national income. To pay the principal becomes a problem and the interest kept on compounding thus reaching a point where the international leaders refused bluntly to lend to Nigeria. As if that was not enough the International Monetary Fund (IMF) stipulated stringent conditions under which they would grant Nigeria further loans.

Nigeria in her desperate quest for money to finance economic growth accepted the foreign loan under those stringent conditions. But these conditions such as devaluation, amongst others hardly improved Nigeria's ability to pay the loan and resulted to what could be termed as external debt crisis. In order to realize the objectives of the study the paper is divided into five sections. Section one is the introduction, section two is an overview of external debt and external debt management policies in Nigeria. The third section captures the research methodology. This is followed exclusively by data analysis and discussion of findings. The remaining section of the paper draws some managerial implications that emerge from the discussion

\subsection{Hypothesis}

Ho: Gross domestic investment, exchange rate, fiscal deficit London Inter-bank offered rate and terms of trade are not the main determinants of external debt of Nigeria.

Hi: Gross domestic investment, exchange rate, fiscal deficit, London Inter-bank offered rate and terms of trade are the main determinant of external debt of Nigeria.

\section{Literature review}

\subsection{The Emergence and Structure of Nigeria's External debt}

In international economics relations, external debt is the term that describes the financial obligation that ties ones party (debtor country) to another (lender country). It usually refers to incurred debt that is payable in currencies other than that of the debtor country. In principle, external debt includes short-term debts, such as trade debts which mature between one and two years or whose payment would be settled within a fiscal year in which the transaction is conducted. External debt may be incurred through a number of transactions such as trade, contractor-finance, supplies credit, private investment and public borrowing. Source of loan that make up external debt include banks, international financial market (euro money and capital markets) international organization e.g. IMF and the World Bank international loans and multilateral private loans.

Foreign loans are organized international credit negotiated between two countries, on terms acceptable to them in today's world, the lender countries are usually the advanced industrialized countries of Europe, Asia (Japan) and North America while the borrowing countries are the poor under developed countries of the thirds word in Africa, Asia and Latin America, From the stand point of the latter, foreign loans are ostensibly for development purposes or to facilitate industrial progress ,or for improving the quality and quantity of food production. The ultimate objective is to increase the standard of living of the generality of the people. (Nwoke, 1990)

The origin of Nigeria's external debts dates back to 1958 when a sum of US \$28 million was contracted for railway construction. Between 1958 and 1977, the level of foreign debt was minimal, as debt contracted during the period were the confessionals debts from bilateral and multilateral sources with longer repayment periods and lower interest rates constituting about 78.5 percent of the total debt stock. From 1978, following the collapse of oil prices, which exerted considerable pressure on government finances, it became necessary to borrow for balance of payments support and project financing. This led to the promulgation of Decree No 30 of 1978 limiting the external loans the federal 
Government could raise to 5 Billion Naira. The first major borrowing of US\$1 billion referred to as jumbo loan was contracted from the international capital market (ICM) in 1978 increasing the total debt to US \$2.2billion

Thereafter, the spate of borrowing increased with the entry of state governments into external loan contractual obligations. While the share of loans from bilateral and multilateral sources decline substantially borrowing from private sources also increased considerably. Thus by 1982, the total external debt stock was US $\$ 13.1$ billion. Nigeria's inability to settle her import bills resulted in the accumulation of trade areas amounting to US 9.8 billion, between 1983 and 1988. The insured and uninsured components were US $\$ 2.4$ and US\$7.4 billion respectively. A reconciliation exercise which took place between 1983 and 1988 with London and Paris club reduced amount to US \$3.8 billion with an accrued interest of US \$1.0 billion bringing the total to US \$4.8 in 1998.

The external debts rose further to US \$33.1 billion in 1990 but declare to US $\$ 27.5$ billion in 1991 and increased steadily to US \$32.6 billion at end of Dec. 1995.

The total debt outstanding at the end of 1999 was US \$28.0 billion with Paris club constituting the highest source with a share of 73.2 percent in 1999 prior to the canvass made for debt cancellation

Contrary to the illusory- image of an "oil-rich" country, Nigeria is a heartily indebted poor country. Its total external debt stock, as at December 2000, is estimated by the Nigerian government at about $\$ 28.3$ Billion it includes arrears amounting to $\$ 14.7$ Billion and late interest of over \$5.Billion. A significant proportion of this debt $(75 \%)$ is owed to official creditors.

The bulk of Nigeria's debt was incurred at non confessional terms during the late 1970s and early 1980s, during a period of significantly low interest rate regime when the London inter Bank offered Rate (LIBOR) hovered between 3 and 4\%.The debt grew rapidly through the eighties due to accumulation of debt service arrears and escalation of market interest rate. LIBOR peaked at $13 \%$ in mid 1989. As a result, the pre-1984 debt of most developing countries, Nigeria inclusive quadrupled by 1990. The collapse in oil price compounded by poor economic policies, bad management and in favorable loan terms, made it externally difficult to service the mounting external debt obligation, particularly those due to the Paris club. Hence despite the rescheduling in 1986, 1989 and 1991 arrears continue to amount, which further worsened the debt problem. Some progress was made however in restricting the commercial debts, and Nigeria has continued to service that category of debt as at when due.

The trend of the external debts highlights the fact that much of the country's external debt is owed to fifteen creditor countries belonging to the Paris club, as a percentage of the total external debt, Nigeria's indebtedness to this group rose almost consistently from about $30 \%$ in 1983 to about $80 \%$ in 2001 . This huge external debt constitutes a major impediment to the revitalization of its shattered economy as well as the alleviation of debilitating poverty. In terms of traditional debt indicators, as shown in the annex, the debt profile started deteriorating during the second half of the eighties, and the reached precautions level in the mid - 1990s, before recording a slight improvement.

As at December 2000, Nigeria's debt stock amounted to about 75 percent of GDP and about 180 percent of export earning. Debt service due in 2000 was about US\$3.0 billion or 14.5 percent export earnings. In 1999, for example spending on health represented and about $0.2 \%$ of GDP and 0.7 percent of GNP compared with 3.4 percent (US\$1.5billion) annual budget spent on debt servicing during the same period. In 2000, US\$1.9 Billion was used for debt7 servicing translating to about 4 times Federal Government budgetary allocation to education and about 12 times the allocation to health while in 2001 debt service payment was US\$2.13 billion which amounted to 6 times of the Federal Government's budgetary allocation to education and 17 times allocation to health for that year. As of December 2004 the total external debt of the country stood as US\$39.9 billion, and US\$20.5 billion as of December 2005. Because of the debt cancellation agreement with Paris Club, the major creditor to the country, the total external debt was greatly reduced to about US\$5 billion as of December 2006.

\subsection{Analysis of the Nigerian external debt management policies and performance}

\subsubsection{Pre -SAP Period: $1962-1985$}

The national economic development planning started with expenditure of $£ 678.8$. Fifty percent of which emanated from foreign sources either in form of foreign private investment or direct foreign assistance to Government. The basic objectives of planning in Nigeria is not merely to accelerate the rate of economic growth and the rate at which the standard of living of the population can be raised, it is also to give an increasing measure of control over its future. (Udoma, 2004)

Nigeria has four different development plans before 1985. These are;

1. The first National Development Programme 1962 - 1968 
2. The second National Development Programme 1970 - 1974

3. The third National Development programme 1975 - 1980

4. The fourth National Development programme 1980 - 1985

The performance of the Nigeria economy during the First Two decades after independence was generally impressive than in the Pre - independence period in spite of the atmosphere of tumultuous political resurgence. The average GDP growth rate was 5.1 percent during First National Development Plan, 8.2 percent under the Second and 5.0 percent under the Third. In the same vein the growth rate of capital formation (investment ration) rose from an average of

14.1 percent under the first plan to 26.7 percent in the third plan. Yesufu (1996) judged the actual performances of the economy, the period between 1981 -1985 (The fourth National Development Plan ) proved to be relatively the most dismal in the economic history of the country, at last since Planning as a strategy of growth and developments.

The primary per capital consumption that was expected to rise from N 27.5 in 1980 , and maintained a steady growth rate of $6 \%$ per annum shoot up to N 257.8 in 1983. This made savings and investment difficult. High level of inflation made a mess of cost projection and financial projections were too optimistic and simplistic and therefore the revenue targets were easily frustrated by external shocks in the word oil market. By the end of 1984, the Nation was indebted to the tune of N21, 384, 5 million in external debt alone (Yugunda, 2003).

\subsubsection{Structural Adjustment Program (SAP) Period: 1986 - 1991}

The Nigeria SAP was designed to fit the standard IMF - World Bank structural adjustment packages and meant to effectively alter and restructure the consumption and productive the patterns of the Nigerian economy, as well, to dominate price distortions and heavy dependence on the exports of crude oil and imports of consumer and producer good (Anyanwu 1993). The programme was proposed as an economy package designed to rapidly and effectively transform the national economy over a period of less than two years (Yesufu, 1996).

According to Adeyemi (1996), the philosophy of SAP was predicated on demand management as a measure of curtailing external imbalance with a restrictive monetary policy. The ultimate objective was to achieve non - inflationary growth and to stimulate domestic production of tradable goods. In addition, SAP was to achieve a sustainable external debt service profile and hence, domestic savings and investment and the inflow of external resources.

The economic performance under the structural adjustment programme appears to have performed better in terms of sectoral and over all GDP growth rates. This is attributable to positive development in the agriculture, oil and financial sectors. The programme also corrected the over - valuation of the Naira which was a major cause of cheap import, enhanced the Government revenue which consequently reduced the need to borrow.

However, the external debt burden increased from US\$19.5 billion in 1985 to US\$34.4 billion in 1991 as a result of new borrowings, increased in foreign interest rate, Capitalization of unpaid interest charges as well as the appreciation of exchange rates of various European and Japanese Currencies against US dollar. The debt service ratio which stood at an animal average of $16.3 \%$ between 1982-1985 increased to 26.7 percent between 1986 - 1994 creating a great strain on the foreign exchange earnings and reflecting the failure of the debt rescheduling programmes mapped out by the London and Paris Club Creditors (Adeyemi, 1993).

The pains of SAP however, include endemic inflation, foreign exchange shortage, sharp increases in unemployment, deterioration in health and educational standard, low capacity was introduced in 1945. The growth rate of GDP per annum was only1.5 percent (compared to 5.3 percent, 13.2 percent and 4.6 percent under First Three National Development Plan). The situation is when calculated in US Dollars terms. The devaluation of Naira increased imbalance in the external trade and the external reserves stagnated and declined. While money income was falling, the cost of living was escalating destroying the welfare of the citizen. Over N80m was spent on food importation alone between 1981 and 1984 in spite of the much celebrated green revolution programme.

Agricultural however came to dominance viz - a - viz mining as a contributor to GDP. 9 utilization and ever - rising fiscal deficits (Anyawu et al 1997). There was no efficiency in resources mobilization as savings refused to translate into investment (Adeyemi 1996).

\subsubsection{Post SAP Period: 1997- 1998}

The external sector came under severe pressure in 1995 with the balance of payments recording further deficits. On the external scare, the balance of payment deteriorated further than 1994 as well as the current of account's deficit. The letter was a result of relatively higher import level coupled with sharp increases in net out payment of services and income which were huge enough to offset the improvement in export earnings. 
There was also further accumulation of debt service arrears, as the nation did not meets the obligations as they fell due. Both the autonomous and parallel market exchange rates closed significantly averaging N82.3: US\$1 and N83.7: US\$1 respectively.

In 1997 there was downward pegging of allocation for debt serving since other options are being explored to solve the debt problem. This was to allow more foreign exchange to be made available for domestic used. It was generally agreed that the Government should as a matter of policy not take any external loan except such are given on concessionary grounds and these should be used only for export - increasing or import - decreasing activities that can pay their ways back. (CBN, 1999)

\subsubsection{Democratic Period: 1999 - 2006}

Nigeria External debt stock in 1999 remained at about the same level as it was in 1988-US\$28.77 billion. In spite of the lifting of the embargo on foreign loans, no new loans were contracted. However, some categories of debt were not serviced, particularly those owed to the Paris Club Creditor Country as well as arrears on post cut off date debt. In spite of the resources constraints, the sum of US\$1.5 billion was set apart to service external debt in year 2000 while arrangement continues on debt reduction negotiation with creditors.

The Government resumed concessionary borrowing multilateral and bilateral sources especially from the word Bank. Borrowed funds were strictly to be used for projects with satisfactory social and infrastructural projects and export-increase / import-decreasing features for economic projects Obadan (2004).

The debt overhang of US $\$ 31.0$ billion in 2004 constituted a deterrent to private investment and generally to growth and development. The government in its budget proposed to service her external debt in a satisfactory manner without compromising the requirements for domestic growth. This is because a group of creditors whose debt must be serviced as at when due, otherwise the serious consequences may result to the country.

Also in the plight of sourcing for substantial debt cancellation, it will help improve the image of the country with its creditors. There is the strong need for Nigeria to seek substantial relief from the heavy debt burden through initiatives that have features of debt reduction. A serious implementation of the NEEDS reform

\subsection{External debt management strategies in Nigeria}

In the 1980, the management of the external debt became major responsibility of the central Bank of Nigeria (CBN). This necessitated the establishment (setting up) of a Department in collaboration with Federal Ministry of Finance to the management of external debt. Although the debt management strategies and measures varied from time to time since the early 1980s, when the external debt became pronounced. The following measures were used by the Government as guidelines to external borrowing.

- Economic sector should have positive Internal Rate of Return (IRR) as high as the cost of borrowing i.e. interest.

- External loans for private and public sectors projects with the shortest rate of return should be sourced from the international capital market while loans for social services or infrastructure could be sourced from confessionals financial institutions.

- State Government, Parastatals, Private sectors borrowing receives adequate approval from the Federal Government so as to ensure that the borrowing conforms to the national objectives.

- Projects to be financed with external loan should be supported with feasibility studies which include loan acquisition, deployment and retirement schedules

- State Governments and other agencies with borrowed funds should service their debts through the foreign exchange market and duly inform the Federal Ministry of Finance for record purposes. Any default will attract deduction (in Nigeria equivalents) at source before the release of statutory allocations.

- Private sector, industries that are export - oriented are expected to service their debt from their export earnings while others should utilize the Foreign Exchange Market facilities for debt servicing.

The government over the years adopted the under listed strategies and measures to deal with the debt problem. They include:

1. Embargo on new Loans and Directives to State Government to restrict external borrowing to the barest minimum. The embargo was to check the escalation of total debt stock and minimize additional debt burden. However, these have not been particularly effective as indiscriminate quest for external loans have not been adopted. Although rescheduling has conferred short term relief or debt service obligations, the debt over-hang has however hardly be abated as the debt stock has continued to increase significantly. 
2. Limit on debt service payments: This requires setting aside portion of export earnings to allow for internal development.

3. Debt Restructuring: This involve the reduction in the burden of an existing debt through refinancing, rescheduling bring back, issuance of collateralized bonds and the provision of new money.

The Federal Government in year 2001 established a semi - autonomous debt management office under the Presidency. The creation of DMO (Debt Management Office) consolidated the debt management functions in a single agency, ensuring proper coordination of the Country's debt recording and management activities, including debt service forecast, debt service repayments, and advising on debt negotiation as well as new borrowings.

\subsection{The pillars to sustainable debt management}

Sustainable management of debts rests on five key pillars

-Improving institutional arrangement for debts

-pursuing appropriate macroeconomic and structural reforms which enhance potential of the economy and increases debt carrying potentials, hence an important component to sustain debt management

\subsubsection{The establishment of DMO}

Prior to the establishment of DMO, debt management in Nigeria was characterized by systematic and structural deficiencies,

-Diffusion of responsibilities across numerous agencies;

-Inadequate debt data recording system and poor information flows across agencies;

-Inaccurate and incomplete loan records;

-Complicated and inefficient debt service/ payment arrangement;

-Low quantity human resources and poor incentive system;

-Lack of a coherent, well defined debt strategy.

It was against the background of these lacunae that the Debt Management Office (DMO) was established. The specific functions of the DMO include,

-Maintaining comprehensive, accurate and timely records of the country's debts;

-Provision of timely and accurate information to assist policy;

-Management to balance transparency, efficiency and cost effectiveness;

-Bringing debt stock and debt service payment down manageable, sustainable levels through debt rescheduling/relief;

-Ensuring proactive debt management strategies to seek advantages of market opportunities;

-Formulating borrowing policies to prevent excessive building of debts while ensuring productive use of borrowed resources.

Pursuing appropriate macroeconomic and structural reformed which enhance growth potential of the economy and increases debt carrying potential, hence an important complement to sustained debt management.

-Prudently managing the debt portfolio and ensuring its effective servicing;

-Advising government on national debt strategy and borrowing policy;

-Assisting in debt relief negotiations and debt restructuring with creditors.

\subsubsection{Proactive debt management}

In order to improve on sustainability of debt management, a debt management office (DMO) was created by Nigeria government to assume more proactive management of commercial debts. Proactive management of debt involves continuously seeking possibilities to restructure debt by taking advantage of market opportunities. The current effort to restructure Nigeria's commercial debt will be driving by the following objectives,

-Reduction in level of debt through debt changes and opportunistic buy backs;

-Obtaining cash flow saving and reduce debt service payments over the short to medium term through alteration of maturity profile;

-Achieving NPV savings. 
Removing onerous legal terms associated with current instruments in portfolio. Successful restructuring of commercial debts will also help a reputation for proactive debt management.

Enshrining appropriate borrowing policies:

Nigeria's external debt experience has shown that inappropriate, uncoordinated and excessive levels of borrowing as well as inefficient allocation of borrowed resources has contributed to the unsustainable debt burden and prevented the country from deriving optimum benefits from external borrowing. DMO has spearheaded the formulation of guidelines for external borrowing. Indicating the broad parameters for the appropriate level, terms and purpose of borrowing that could be contracted on priority sectors;

-Stipulating general criteria for approval of these borrowing

-Servicing arrangement for the loans

Since external loans must be repaid in foreign exchange, external borrowing decisions must be linked to a general economic policy framework that will guarantee both profitability of the invested borrowed funds and the generation of sufficient foreign exchange for external funds-increasing or import- decreasing projects. The DMO is designing a debt management framework that ensures

(a) A functional and early warning signal of debt crisis and,

(b)An appropriate currency composition of external debt and hedging to maximize exchange rate and interest rate losses from possible shifts in terms of trade and the balance of payments.

The guidelines for eternal borrowing also ensure transparency and set out due process rules in the approval of these borrowings. For instance, the Federal Executive Council (FEC) in formulating the new borrowing guidelines stipulates that Federal and State Government wishing to obtained external loans must first get Federal Government approval in principle before getting into full negotiations for the loans. To qualify, the state must show evidence that it has not over borrowed in the past. The tending borrower must also issue an irrevocable letter of credit to the Ministry of Finance authorizing it to service the loan. All external loans which must be supported by Federal Government guarantee must show evidence that the National planning Commission had clear their feasibility and viability. Borrowings are also to be limited to highly concessional sources, which imply that the grant element must not be less than 60 per cent. The new borrowing guidelines also demand that each loan must have a moratorium of at least 10 years before take commencement of payments. The DMO currently plays a key role in a review process and advices government accordingly on new borrowings. The arrangement has helped control reckless borrowing. 2.4.3 Pursuing appropriate macroeconomic policies

Effective and efficient debt management policies must predicted on the existence of the overall macroeconomic management framework of which debt management is an integrated component. Previously, poor economic management and bad governance have placed a major role in the economic and problems of Nigeria. The debt overhanging only compounded most of the underlying structural and institutional problems retarding development (Anyingang, 2008). Therefore, the committed implementation of appropriate macroeconomic policies along with debt reduction packages will ensure that reduction provides the much needed stimulus to investment recovery and growth. Some desirable element of sound macroeconomic management policies include,

- Maintaining domestic saving to reduce the reliance of foreign finance

- Boosting domestic saving to reduce the reliance

- Creating a favorable investment climate and initiating policies to promote foreign direct investment.

- Gradual disengagement of government from productive activities in the context of privatization and commercialization of state owned enterprises.

\section{Research methodology}

The study seeks to appraise the relationship between external debt management polices and economic growth in Nigeria. Ex-post facto research design was adopted for this study. Secondary data were obtained from the Central Bank of Nigeria (CBN) publications of 1970-2006. The data would be analyzed and interpreted in order to facilitate a vivid conclusion on the effect relationship between external debt management polices and economic growth of Nigeria.

The major statistical tool used in this study is the ordinary least square (OLS) regression technique. To carryout this study, certain model were build in line with the hypotheses to help analyze the study better, thus:

$$
\text { LEDEBTt }=\mathrm{a} 0+\mathrm{a} 1 \text { LGDIt }+\mathrm{a} 2 \text { LEXCHRt }+\mathrm{a} 3 \text { LFISDYt }+\mathrm{a} 4 \text { LLBORt }+\mathrm{a} 5 \text { LTOTt }
$$


a prior, a $>0, a 1>0, a 2>0, a 3>0, a 4>0, a 5>0$

Where: the following are variable list used:

LFDEBTt $=\log$ of external debts in current period

LGDI $=\log$ of gross domestic in current period

EXCHRt $=$ exchange rate (Naira/US dollars) in current period

FISDYt $=$ fiscal deficit income ratio in current period

LIBOR $=$ London inter-bank interest rate in current period

TOT $=$ Terms of trade in current period

\section{Data presentation analysis and discussion of findings}

\subsection{Data presentation}

$<$ Table 1 about here $>$

Nigeria's high debt burden had graved consequences for the economy and the welfare of the people. The servicing of the external debt had severely encroached on resources available for socio-economic development and poverty alteration. Although since 1986, Nigeria had taken a decision to limit debt service to no more than 30 percent of oil receipts; this has not brought much relief.

Between 1985 and 2005, Nigeria spent 'over US\$52 billion on servicing external debt. Creditors annual debt service payment due were in the range of US\$3.0 billion to US\$3.5 billion. Debt service due in year 2000 was over US\$3.1 or (14.5 percent of export earning) excluding arrears of US\$19.6 billion owed to members of Paris club. Actual servicing outlays in year 2000 was US $\$ 1.9$ billion translating to about 4 times Federal Government's budgeting to alleviate education and about 12 times the allocation to health. Yet these two sectors need substantial public expenditure to upgrade the level of facilities and services for any meaningful alleviation of poverty to take place. Also, the external debt overhang had adverse impact on the Nigeria's economy in the inflow of foreign investments. Due to Nigeria's problem with servicing of her debts, Export credit Guarantee

Agencies (ECGAS) suspended insurance cover for exports for goods and services as well as investment capital to the Country. Consequently, the much needed inflow of foreign resources for investment stimulation, growth and employment has been hampered. Without credit cover, Nigerian importers are required to provide $100 \%$ cash covers for all orders and this therefore place them to a competitive disadvantage compared to their counterpart else where.

The situation exacerbates the pains of external burden as it blocks off the relief that would have been received through speedy economic recovery, growth and development. In addition, external debt burden resulted in repudiation risk because we were unable to obtain new loans due to little confidence placed on our ability to repay. The prospects therefore dim for immediate resumption of net resource transfer from international sources to Nigeria through traditional means. The IMF severe conditionality for Nigeria is a case point. A severe reduction in net capital inflows and the imposition of a net capital outflow over an extended period had consequences on the prospects of economic development in Nigeria. In the face of dwindling oil revenues due to oil glut and fast falling prices but rising imports, balance of payment difficulties are bound to arise. i.e. external liabilities will rapidly increase, therefore raising the real resource cost of the original loans while leading to future foreign exchange crisis.

The cost of import substitution will rise. This is because this sector contributes heavily to external debt service and to profits and dividends outflows. For instance, as a result of the Nigerian government to service her debt before year 2000, there was severe austerity measures on Nigerians in an attempt to survive the external debt crisis. According to the DMO report the evolution of Nigeria's external debt since 1983 disaggregated into official external debt and private external debt. The sustainability of the debts is reflected in three main indicators namely, ratio of total debt service to export earnings (TDSX) or debt service ratio, ratio of total external debt to GDP (EDTY), and the ratio of total debt service to government revenue (TDS/REV). The external debt GDP (EDTY) in 1987 was about 106 per cent, while the total debt services as percentage of fiscal revenue was about 33.7 per cent in 1991 as shown in table 1 . The total debt to export earnings was about 438.5 per cent in 1988 as seen in table 1. From 1986, Nigeria had taken a decision to limit debt service to not more than 30 per cent of oil receipts. The foregoing analysis shows that Nigeria had been a precarious debt situation since 1980s as measured by traditional indicators as shown in table 1 .

\subsection{Data analysis}

<Table 2 about here $>$ 
At this point, we present the regression result of GDI, exchange rate, fiscal deficit, London Inter banks offered rate and term of trade on external debt. The quantitative results revealed that

(a) The coefficient of gross domestic investment (GDI) is positive. This implies that, increase in GDI will increase external debt. In order words, for GDI to increase external debt must also increase. This is in line with our econometric a priori theoretical expectation. Specifically, the result shows that if all the explanatory variables are held constant a one per cent increase in GDI can be induced by 0.718731 per cent increase in external debt. Therefore, if external debt would have been directed towards growth and development, Nigeria could have been boosting of 0.71 per cent of growth in investment rate contributed by external debt only. The unfortunate part of it is that these external debts over the years are taken to finance balance of payment deficits. This coefficient of external debt is statistical significant at one per cent level of significance.

(b) The coefficient of exchange rate is positive, meaning that there exist a positive relationship between exchange rate and acquisition of external debt in Nigeria. This relationship although not in line with economic a priori criteria, it is accepted in the case of Nigeria because the balance of payments must be balanced the end of any financial year. As such Nigerian authorities have no option than to obtain loans from external sources to finance their balance of payments deficits. Although the result shows that if all the other factors specified in the external debt equation are at zero a one per cent increase in foreign exchange rate will ginger up 0.411363 per cent of external debt. This might not be obvious because exchange rate hardly influences third world countries borrowing.

(c) The estimated coefficient of fiscal deficit is positive. This shows that there exist a positive relationship between foreign debt and government fiscal expenditure in Nigeria. Although the relationship is supported by the classical debt management theory, it is also a pointer to the factor that the fiscal deficit financing is made possible through external debt. This factor occupies a significant position in our external debt equation.

(d) The estimated coefficient of London Inter bank offered rate (LIBOR) is positive and not consistent with economic a priori criteria. Although this estimate is statistically significant at one per cent level, it makes no sense in the case of debt obtained under compulsion. That is, since Nigerian's debt in this context is obtain to finance balance of payments deficits, Nigeria will continue to demand for more loans from the London banks even with increase in their offered rate especially when there is no better alternative.

(e) The coefficient of term of trade is positive. The result shows that there is a positive relationship between terms of trade and external debts in Nigeria. The result shows that if all explanatory variables are held constant, any one percent increase in terms of trade is made possible by 0.0054362 per cent increase in external debt. The estimated coefficient of terms is statically significant in external debt equation.

(f) The value of the adjusted R2 is 0.914745 . This shows that the regression line captures more than 91 per cent of the total variation in external debt caused by variation in the explanatory variables specified in the external debt equation with less than 9 per cent accounting for the error term of trade. The test of autocorrelation using D.W test shows that the D.W value of 1.12321 falls within the inconclusive region of D.W partition curve. Hence, we cannot clearly say whether autocorrelation exist or not.

\subsection{Discussion of results}

Responding to our first hypothesis sated in the null form (Ho) that Gross domestic investment, exchange rate, fiscal deficit, London inter bank offered rate and terms of trade are not the major determinants of external debt in Nigeria between 1970 and 2006.

Our regression results show that the above mentioned variable accounted for more than 97 per cent of the total variation in external debt while less than 9 per cent is accounted for by the stochastic error term. The joint test of significance of all parameter estimate conducted using the F- statistics shows that the observed $\mathrm{F}^{*}$ ratio of 37.0041 is greater than the theoretical value at one per cent level of significance. Hence we say that our estimated results of the external debt equation are 99 percent reliable. Therefore we reject our null hypothesis and accept the alternative hypothesis with the conclusion that GDP, exchange rate, fiscal deficit, London inter bank lending rate and terms of trade are strongly determinant of external debt in Nigeria and that variation in external debt in Nigeria must be through variation in those factors

\section{Conclusion and policy recommendations}

\subsection{Conclusion}

The primary objective of the study was appraisal of external debt management policies on the economic growth of Nigeria. The analysis showed that the economic variables employed have high and obvious effect on the economic 
growth proxied by the gross domestic product and gross domestic investment in the function specified. This seen in the high coefficient of determination and the F ratio of all the model specified. The D.W shows that the functions are stable and therefore good for economic policy making

Also the analysis showed that the debts crisis in Nigeria had adverse effect on economic growth, therefore, there is need for appropriate policies with respect to debts variables for sustainable economic growth.

\subsection{Policy recommendation of the study}

Given the outcome of our regression result, the following recommendations were made

1. The federal government should lay down well considered guideline for external loans. Defining the purpose, duration, moratorium requirements and commitments, negotiation fees etc including the conditions under which the government can approve and guarantee external loans

2. The use of more superior method to negotiate for fixed interest payment and varying amortization schemes. Nigeria should seek multi-year rescheduling rather than year by year basis.

3. External finance should be used only for projects of highest priority. This is so because it is huge external debt that threw us into the series of economic problem in the first instance.

4. To achieve a long term solution to the external debt problem there must be vigorous promotion of the nations export trade and drastic reduction in her merchandize imports.

5. Nigeria should devote a tangible proportion of her annual foreign exchange earning for debt servicing. This would enable the counting to accommodate the creditors' requirements.

6. Spending of external debt on productive self-liquidating investment must be strictly adhered to while projects to be financed with external to loan must be properly appraised.

7. In view of the debt relief, government should ensure that spending impact on poverty reduction halts HIV/AIDS and malaria and addresses child and material mortality. Thus, the government should priorities its spending on health, education, water, infrastructure, power and agriculture.

8. The money saved from external debt servicing should be ploughed into poverty reduction programmes boosting agriculture and other sectors of the economy.

\section{References}

Adeyemi (1996). Beyond Structural Adjustment: A policy Framework", In Beyond Adjustment: Bullion CBN Publication, 9(1) $24-30$

Anyanwu, T. (1993). Impact of Nigerian external debt on the economy. Lagos. Journal of Monetary Economy, 2 (1) 21-26

Anyanwu, T. (1997). Drops of oil in a sea of poverty - the case of a new debt deal for Nigeria. Retrieved on July $24^{\text {th }}$ 2007 from www.jubilee.plus.org.

Anyingang, R. (2008). The appraisal of the impact of external debt management policies on economic growth in Nigeria. Unpublished MSc. thesis, presented to Graduate School, University of Calabar

Ayejide, T. (1985). Nigeria Federal finance and prospect.

Nwoke, C. (1990). The Origins and Dimension of Nigeria External debt: In Nigeria External Debt Crisis; Its Management. Lagos: Malthouse Press Ltd

Obadan, M. (2004). External Sector Policy. Bullion CBN Publication, 28 (1) 30 - 40

Osie, G. (1995). Ghana: The burden of debt service payment under structural adjustment. Africa Economic Research Journal 4 (1) 1-5

Ovat, O. \& Uket, E. (2003). External debt crisis and economic growth in Nigeria. Nigerian Journal of Economics and Development Matters, 2 (1), 85-97

Stephen, M. (1999). The change role of export credit agencies. Washington D.C IMF

Udoma, U. (2004). Nigerians External Debt Burden. Ibadan, Fountain Publication, Pp 31-40

Yesufu (1996). The Nigerian Economy: Growth without development, Bennin Social Series for Africa, 89 - 110.22 
Yuguda, L. (2003). Management of External Reserves: paper presented at $13^{\text {th }}$ annual internal auditors conferences, CBN, Kaduna 27-30 November

Table 1. External debt indicators 1970-2006

\begin{tabular}{|c|c|c|c|c|c|c|}
\hline Year & Ext. Debt & EDTX\% & EDTY\% & BOP & TDS/REV\% & TDSX $\%$ \\
\hline 1970 & 684 & 42.2 & 3.11 & -46.6 & 2.4 & 2.5 \\
\hline 1971 & 310 & 36.3 & 3.36 & -117.4 & 2.56 & 2.31 \\
\hline 1972 & 400 & 33.9 & 3.86 & $\begin{array}{l}-52.2 \\
\end{array}$ & 1.86 & 1.86 \\
\hline 1973 & 421 & 34.9 & 2.52 & -192.0 & 1.82 & 1.82 \\
\hline 1974 & 523 & 13.9 & 1.8 & $-3,102.2$ & 0.64 & 0.64 \\
\hline 1975 & 559 & 14.3 & 1.64 & -157.5 & 0.59 & 0.59 \\
\hline 1976 & 594 & 8.6 & 1.39 & 339.0 & 0.51 & 0.51 \\
\hline 1977 & 763 & 26.6 & 1.56 & 527.2 & 0.32 & 0.32 \\
\hline 1978 & 5,091 & 48.2 & 3.79 & $-1,293.6$ & 2.18 & 2.52 \\
\hline 1979 & 6,216 & 25.1 & 4.01 & $1,868.9$ & 1.67 & 1.76 \\
\hline 1980 & 8,855 & 34.1 & 3.79 & $-2,402.2$ & 0.67 & 0.72 \\
\hline 1981 & 12,018 & 67.3 & 4.43 & $3,020.8$ & 3.86 & 4.65 \\
\hline 1982 & 12,815 & 105.4 & 17.13 & $1,398.3$ & 6.76 & 8.43 \\
\hline 1983 & 17,785 & 177.6 & 22.68 & 301.3 & 12.71 & 17.22 \\
\hline 1984 & 17,347 & 155 & 21.06 & -354.9 & 23.46 & 28.89 \\
\hline 1985 & 18,904 & 153.8 & 23.68 & -349.1 & 8.91 & 32.95 \\
\hline 1986 & 25,574 & 342.2 & 71.62 & 784.3 & 20.514 & 28.55 \\
\hline 1987 & 28,316 & 407.9 & 106.45 & -159.2 & 11.71 & 10.05 \\
\hline 1988 & 30,693 & 438.5 & 97.6 & $2,294.1$ & 26.01 & 23.001 \\
\hline 1989 & 31,589 & 369.5 & 104.97 & $-8,727.8$ & 29.75 & 25.36 \\
\hline 1990 & 33,400 & 291.5 & 103.71 & $-18,498.2$ & 29.27 & 23.91 \\
\hline 1991 & 33,730 & 252.5 & 104.37 & -5959.6 & 33.71 & 25.71 \\
\hline 1992 & 27,565 & 210.2 & 87.6 & $-65,272$ & 21.73 & 18.24 \\
\hline 1993 & 28,718 & 262.2 & 92.68 & $-13,615.9$ & 20.52 & 16.18 \\
\hline 1994 & 29,429 & 300.6 & 70.68 & $-42,623.3$ & 19.97 & 18.83 \\
\hline 1995 & 32,585 & 312.6 & 74.78 & $1,95.216$ & 21.19 & 15.20 \\
\hline 1996 & 28,060 & 200.5 & 86.11 & $-53,152$ & 30.34 & 13.41 \\
\hline 1997 & 27,287 & 200.6 & 81.22 & $1,077.7$ & 21.54 & 10.94 \\
\hline 1998 & 28,773 & 308.5 & 92.93 & $-220,667$ & 28.38 & 16.05 \\
\hline 1999 & 28,039 & 226.6 & 82.89 & $-326,638$ & 34.57 & 10.29 \\
\hline 2000 & 28,274 & 147.8 & 59.38 & $314,147.2$ & 26.47 & 9.02 \\
\hline 2001 & 28,347 & 153.9 & 59.40 & $24,729.9$ & 33.04 & 11.9 \\
\hline 2002 & 30,990 & 180.2 & 62.3 & -565.353 & 8.80 & 7.5 \\
\hline 2003 & 32917 & 176.9 & 64.4 & $-162,839$ & 11.6 & 9.8 \\
\hline 2004 & 35.9 & 17.3 & 63.6 & $8,452.2$ & 9.10 & 8.5 \\
\hline 2005 & 20.5 & 16.9 & 58.8 & $10,366.4$ & 8.9 & 7.89 \\
\hline 2006 & 5.0 & 10.5 & 46.8 & $3,804.8$ & 8.56 & $6.98 \mathrm{~s}$ \\
\hline
\end{tabular}

Ext. Debt $=$ external debt in million US \$. , BOP $=$ Balance of payment $(\mathrm{N}, \mathrm{m})$; EDTY\% $\%$ external debt GDP, EDTX\% $=$ debt/export ratio; TDSX = debt service ratio; $\mathrm{DS} / \mathrm{REV}=$ debt service to government revenue

Source: Statistical bulletin 2006 and DMO 
Table 2: External debt equation

\begin{tabular}{|c|c|c|c|c|}
\hline Variable & coefficient & Std. error & t- value & P-value \\
\hline Constant & 0.223896 & 0.111617 & 2.00594 & 000 \\
\hline LGDI & 0.1718731 & 0.615400 & 13.30286 & 000 \\
\hline EXCHR & 0.41135 & 0.676383 & 3.72948 & 000 \\
\hline FISDY & 0.38333 & 0.034239 & 1.61743 & 001 \\
\hline LIBOR & 0.68427 & 0.059922 & 3.91743 & 000 \\
\hline TOT & 0.00544 & 0.006045 & 3.42856 & 001 \\
\hline
\end{tabular}

$\mathrm{R} 2=0.914743$

F-statistics (6.21)

D.W Statistics 1.12321

Dependent variable: External debt

Equation 4.1 External debt equation 